DOI: doi.org/10.21009/IJLECR.062.18

Received: 15 June 2020

Revised: 7 July 2020

Accepted: 5 November 2020

Published: 1 December 2020

\title{
MOTIVATION FOR LEARNING SPEAKING SKILLS USING VIDEO BLOG (VLOGGING) \\ BASED ON PROJECT LEARNING STUDENTS OF THE INDONESIAN \\ LANGUAGE AND LITERATURE EDUCATION DEPARTMENT AT NUSA CENDANA UNIVERSITY: A PHENOMENOLOGY APPROACH
}

\author{
Yakobus M. Langkelang Niron ${ }^{1, a)}$ \\ Postgraduate Students of Language Education Study Program, Jakarta State University ${ }^{1)}$ \\ yakobusm8.pb19s3@mahasiswa.unj.ac.id ${ }^{\text {a) }}$
}

\begin{abstract}
This study aims to identified students motivation in learning project-based learning (PBL) Indonesian language skills using vlogging media based on meanings and themes seen from the "because motives" and "in order to motives" related to the phenomenon of learning in the classroom. In identifying objectives, this study uses a qualitative research method with the approach of phenomenology from Albert Schutz's perspective. Researcher becomes the main instrument in an effort to obtain and find data. The research subjects were 38 second semester students of the Department of Language and Literature at Nusa Cendana University. Data collection techniques used include observation, questionnaires, and interviews. Data analysis through three stages of the flow model namely reduction, presentation and verification of data and triangulation. The results of the study prove that the teaching strategy associated with vlogs can attract students' learning interest because of their interest in other fields such as multimedia technology and social media. The application of learning PBL-based speaking skills using vlogs can improve speaking competence and gradually improve the mental aspects of students to become more confident to speak and communicate in public. So it can be said that learning PBL-based speaking skills using vlogs is a good and innovative learning strategy in an effort to increase learning motivation and mastery of students' speaking skills.
\end{abstract}

Keywords: motivation, project based learning video blogging, speaking skills, motives.

Motivation becomes an important point or point in determining the process of teaching and learning success. The lower the motivation of students, the level of learning success also becomes low, and vice versa. In the context of learning speaking skills, the low ability to speak can be demonstrated in a mental awareness such as nervousness, fear, doubt when students are asked to speak. This phenomenon makes a learning process not achieved. It can be caused by various factors such as learning strategies, learning media, learning methods, students 'level of understanding, students' mental processes, and so on. According to Sri Wahyu Indrawati, Emzir, and Ninuk Lustyantie (2017) said that learning techniques and level of self-confidence greatly influence the speaking skills in Indonesian discussion. Thus, speaking skills require a lot of language experience by using various speaking techniques so that when someone talks, the message being discussed can be well received by the listener. Tarigan (1998: 43), states that speaking skills are mechanistic 
skills. The more practice the more the speaking skills are mastered. Mastering speaking skills can automatically affect other language skills, including writing, listening and reading, Sulistyaningrum (2016). So that, it requires a variety of approaches to methods and strategies in learning to achieve good speaking skills of teachers and students. This requires the teacher's role as an attack on creators and facilitators of learning in the classroom to arouse students' motivation as the main capital for achieving learning objectives. In line with this statement Fatmawati (2017: 71) argues that motivation is a change in energy in a person which is characterized by the emergence of feelings and reactions to achieve goals. The statement certainly leads to various strategies and methods used by teachers to arouse students' motivation. One of them is using a strategy that has implications for the use of technology.

The use of various technological media in education is a breakthrough as part of innovation in learning, especially learning speaking skills to improve learning outcomes. Siti Yulidhar Harunasari, Aceng Rahmat (2015: 65) state that innovation about Information and Communication Technology (ICT) have an impact on the learning process. Therefore, this study aims to show the motivating factors of learners related to the application of learning models and methods using one of the technologies and information, namely video blogs applied with the project based learning approach to learning Indonesian speaking skills in the Department of Language Education and Indonesian Literature at Nusa Cendana University.

Project-based learning (PBL) is a learning that is designed for complex problems in which students conduct investigations to understand it, emphasizing learning with long activities, multidisciplinary and product-oriented (artifacts) assignments that given to students. Project-based learning approaches are supported by constructivist learning theories. Constructivism is a theory of learning that has broad support and relies on the idea that students build their own knowledge in the context of their own experiences. The opportunity to convey ideas, listen to other people's ideas, and reflect their own ideas on the ideas of others, is a form of individual empowerment experience. The interactive process with peers helps the knowledge construction process (meaning-making process).

According to Mahanal (2009) PBL learning in general has a step guide: Planning Creating, and Processing. Furthermore, it was stated that PBL supports the implementation of learning to achieve the learning objectives of speaking, bearing in mind that PBL is a comprehensive learning process involving students conducting collaborative investigations. PBL helps students in learning solid knowledge and skills that are built by utilizing technology in learning.

A number of studies say that the use of technology as a learning medium is proven to improve learning outcomes. As research conducted by Siti Yulidhar Harunasari, Aceng Rahmat (2015) with the title "CALL-Based Instruction Model of Speaking English (A Developmental Research at the English Language Education Study Program of STKIP Kusuma Negara, Jakarta)" which shows that learning speaking skills English using call-based instruction models has proven to be effective based on the results of tests conducted.

Research conducted by Muhamad Sofian Hadi, Emzir in 2016 entitled "Improving English Speaking Ability Through Mobile Assisted Language Learning (MALL) Learning Model". Using the action research method shows that the use of MALL has been shown to improve the results of students' speaking skills. The process of improvement in speaking English with MALL can increase student involvement as evidenced by an increase in grades in each cycle undertaken. Their involvement in learning tends to increase. This is indicated by the response they give to lecturers, actively asking questions when they don't understand the material being studied, trying to find answers independently with their smartphone devices to use the internet, doing assigned tasks seriously, and doing the homework given to them.

Then, other relevant research is a research conducted by Umi Faizah, Mohammad 
Fakhrudin, Bagiya entitled "Implementation of Youtube Learning Media Da'wah Rhetoric Education Based on Scientific Approaches at Muhamadiyah University Purworejo" in 2017. The research uses qualitative methods that show, 1) Youtube rhetoric learning media for first semester students during Indonesian language and literature education at Muhammadiyah University Purworejo 2016/2017 academic year with an approach that includes scientific observation, questions, exploration, association and effective communication; 2) the first semester students of Indonesian language and literature education study program Muhammadiyah Purworejo University 2016/2017 academic year gave a positive response to the use of YouTube learning media with a scientific approach. This means that the learning done by using the YouTube platform based on a scientific approach is developed into comprehensive learning that is oriented to the concept of HOTS (high order thinking skills) and functional.

From the three studies presented above, it can be said that the use of technology has a positive influence on learning qualitatively and the success of quantitative learning outcomes. The thing that distinguishes the three studies above with the research conducted by the writer is that this research uses another type of technology, video blog as a learning medium and research methodology that is different from the three studies above, namely qualitative research with a phenomenological approach. That is, this study aims to conceptualize various phenomena of learning speaking skills by using video blog media in terms of students' affective or motivational factors.

Albert Schutz's phenomenological approach. Schutz (Amelia, et al, 2018: 1244) states that the everyday social world is something that is intersubjective. Understanding can not be separated from the motive "cause" and motive "purpose". This motive is because refers to past events underlying the individual to take certain actions. The goal motive refers to a situation in the future where the individual wishes to achieve through several actions. The phenomenological approach is related to understanding everyday life, the intersubjective world (the world of life). The purpose of phenomenology is to interpret human social action as a meaningful (interpreted) and be able to reconstruct the derivation of meaning (meaning used next) from meaningful actions in individual intersubjective communication in the world of social life (Creswell, 2017). Phenomenology research tries to describe and uncover the meaning of the concept or phenomenon of experience based on consciousness that occurs in some individuals. Phenomenology is carried out in a natural context, so that there are no limits in understanding and understanding the phenomena under study and the researcher is free to analyze the data obtained.

The phenomenon of video blogs has become a new trend in the development of the world today. Video-Blogging, or can be abbreviated as vlogging (David, 2017: 145) is a form of blogging activities using the video medium above the use of text or audio as the main media source. Various devices such as camera phones, digital cameras that can record video, or inexpensive cameras equipped with microphones are easy assets for vlogging. Vlogs usually tell a variety of things that are packaged attractively with audio-visual features presented by the makers of the vlog so that it becomes interesting to watch and listen to by the audience. The concept of this video blog becomes a strategy to implement the process of learning speaking skills in students of the Department of Indonesian Language and Literature Education, Nusa Cendana University.

\section{METHOD}

This research was conducted using a qualitative method with the phenomenological approach of Albert Schutz's perspective. The focus of this research is the understanding and discovery of meaning construction and themes of student motivation to improve project-based learning-based speaking skills using video blogs. Researcher becomes the main instrument in an effort to obtain and find data. The research subjects were 38 second semester students of the 
Department of Language and Literature at Nusa Cendana University. Data collection techniques were collected by observation, questionnaires and in-depth interviews focused on statements, meanings, meaningful themes, general description of the subject's experience; including analysis of the context used include observation, questionnaires and in-depth interviews. Observation is used with the intention to observe and record the symptoms that appear on the object of research at a time or situation that is natural or actually ongoing. The questionnaire was used to obtain textual data related to student perspectives on learning motivation in learning speaking skills. The questionnaire used is open questionnaire type. Interviews were made by researchers to obtain various data about feelings, level of interest, competence, learning strategies in learning speaking skills. Then the results of questionnaires and interviews are made in the form of a transcript in the form of textual descriptions used in data analysis.

Data analysis through three stages of the flow model namely data reduction, presentation and verification. Bungin (2006) says that all three stages take place simultaneously. The technique used to check the validity of the data and the saturation of the data is the perseverance of observation and triangulation. Triangulation is done in two ways, namely triangulation through sources and triangulation through theory. Triangulation through sources is used to compare interviews and questionnaires and instructor strategies in applied learning. Triangulation through theory is used to study the results of research findings based on existing theories.

\section{RESULTS AND DISCUSSION}

The learning motivation of the second semester students of the Department of Language and Literature at the University of Nusa Cendana in the application of learning skills using projectbased learning based vlogging media was examined from the perspective of Alfred Schutz's phenomenology. Schutz's perspective of phenomenological research explains the critical reflection of human consciousness by describing human consciousness into two motives underlying human action, namely the motive "cause" and the motive "purpose."

\section{Because Motives}

Because motive is a motive for someone to act that puts forward the reasons why someone did certain actions with reference to the past, for example the statement "I study hard because my cognitive value is decreased". The existence of these statements can be seen that the act of learning hard is due to past experiences that show a decreased cognitive value. From this statement, then the motive is the motive "cause", this is due to actions that refer directly to past events (cognitive value decreases) as the cause of these actions, (Campbell, 1994: 270). Based on the explanation above, matters relating to meanings and themes as "cause" motives based on the perspective of students in this study, can be seen in the following table:

Table 1. Motive "Because" of Student Learning Motivation in Learning Indonesian Speaking Skills using Project Based Learning Vlogs

\begin{tabular}{|c|l|l|l|l|}
\hline No & Respondent & \multicolumn{1}{|c|}{ Social Context } & \multicolumn{1}{|c|}{ Mean } & \multicolumn{1}{|c|}{ Theme } \\
\hline 1 & Andi & $\begin{array}{l}\text { The class atmosphere is fun } \\
\text { because it's always interspersed } \\
\text { with watching vlogs and making } \\
\text { vlogs }\end{array}$ & $\begin{array}{l}\text { Students fodents do } \\
\text { happy } \\
\text { watching vlog } \\
\text { not in } \\
\text { saturated in } \\
\text { the teaching } \\
\text { and learning } \\
\text { process }\end{array}$ \\
\hline 2 & Ade & $\begin{array}{l}\text { Speaking in front of the camera is } \\
\text { a challenge for me, and in my } \\
\text { opinion it is very fun if while } \\
\text { studying because it is not } \\
\text { saturated }\end{array}$ & $\begin{array}{l}\text { Students } \\
\text { Challenging and } \\
\text { doing fun learning }\end{array}$ & \\
\hline
\end{tabular}




\begin{tabular}{|c|c|c|c|c|}
\hline 3 & Rina & $\begin{array}{l}\text { Classes become unsaturated } \\
\text { because every material is always } \\
\text { interspersed with vlog examples } \\
\text { and then practiced }\end{array}$ & \begin{tabular}{lr} 
Students do not \\
feeling bored \\
because & the \\
material & is \\
interspersed with \\
\multicolumn{2}{l}{ watching vlogs }
\end{tabular} & \\
\hline 4 & Dedi & $\begin{array}{l}\text { We always watch videos about } \\
\text { the vloggers' style of speaking in } \\
\text { class so that there is no boredom } \\
\text { when following a speaking } \\
\text { course }\end{array}$ & $\begin{array}{l}\text { Students don't feel } \\
\text { bored because of } \\
\text { watching vlogs }\end{array}$ & \\
\hline 5 & Sinta & $\begin{array}{l}\text { The lecturer delivered the } \\
\text { material clearly, well and } \\
\text { correctly, coupled with a } \\
\text { spectacle from the vlog and } \\
\text { material about making vlogs }\end{array}$ & $\begin{array}{l}\text { Submission of } \\
\text { material through } \\
\text { examples of vlog } \\
\text { speaking activities } \\
\text { is felt clearly by } \\
\text { students }\end{array}$ & \multirow{4}{*}{$\begin{array}{l}\text { Clarity } \\
\text { Discussion of } \\
\text { material by } \\
\text { lecturers } \\
\text { associated } \\
\text { with watching } \\
\text { vlogs related } \\
\text { to speaking } \\
\text { activities }\end{array}$} \\
\hline 6 & Haris & $\begin{array}{l}\text { I quickly understood the } \\
\text { techniques of speaking well } \\
\text { because } \\
\text { immediately shown through } \\
\text { vlogs }\end{array}$ & $\begin{array}{l}\text { Student could } \\
\text { understanding the } \\
\text { material based on } \\
\text { vlog examples }\end{array}$ & \\
\hline 7 & Linda & $\begin{array}{l}\text { The lecturer always gives } \\
\text { freedom to students to watch any } \\
\text { vlog then the lecturer discusses } \\
\text { and connects with the material. }\end{array}$ & $\begin{array}{lr}\text { The lecturer } \\
\text { connects } \\
\text { material the } \\
\text { speaking } \quad \text { of } \\
\text { with examples of } \\
\text { watching vlogs }\end{array}$ & \\
\hline 8 & Randi & $\begin{array}{l}\text { The learning starts from watching } \\
\text { the vlog then the lecturer explains } \\
\text { the material. That makes me } \\
\text { understand more quickly }\end{array}$ & $\begin{array}{l}\text { The learning phase } \\
\text { begins with } \\
\text { watching a vlog } \\
\text { then the delivery } \\
\text { of material that } \\
\text { addresses matters } \\
\text { relating to aspects } \\
\text { of speaking }\end{array}$ & \\
\hline 9 & Kristo & $\begin{array}{l}\text { The discussion was exciting } \\
\text { because we discussed with the } \\
\text { lecturers and friends discussing } \\
\text { the mistakes of speaking in the } \\
\text { vlogs they were watching. That } \\
\text { makes us understand aspects of } \\
\text { speech }\end{array}$ & $\begin{array}{l}\text { Students are } \\
\text { interested in } \\
\text { discussions that } \\
\text { discuss speaking } \\
\text { errors in vlogs }\end{array}$ & \multirow[t]{2}{*}{$\begin{array}{l}\text { Tasks and } \\
\text { discussions } \\
\text { are based on } \\
\text { the cases } \\
\text { speak of the } \\
\text { vlog. }\end{array}$} \\
\hline 10 & Dian & $\begin{array}{l}\text { We discussed about the vlogs we } \\
\text { watched by paying attention to } \\
\text { the detailed aspects of speaking } \\
\text { and videography, it was really } \\
\text { fun }\end{array}$ & $\begin{array}{l}\text { Students are very } \\
\text { interested in } \\
\text { discussing aspects } \\
\text { of speaking } \\
\text { through vlogs and } \\
\end{array}$ & \\
\hline
\end{tabular}




\begin{tabular}{|c|c|c|c|c|}
\hline & & & $\begin{array}{ll}\text { aspects } & \text { of } \\
\text { videography }\end{array}$ & \\
\hline 11 & Ayu & $\begin{array}{l}\text { We are free to choose the topic to } \\
\text { speak according to your interests } \\
\text { and interests }\end{array}$ & $\begin{array}{l}\text { Students can } \\
\text { choose the topics } \\
\text { according to their } \\
\text { interests. }\end{array}$ & \multirow{3}{*}{$\begin{array}{l}\text { The types of } \\
\text { practice of } \\
\text { speaking } \\
\text { activities and } \\
\text { topics of } \\
\text { conversation } \\
\text { are determined } \\
\text { based on } \\
\text { students' } \\
\text { interests }\end{array}$} \\
\hline 12 & Ari & $\begin{array}{l}\text { Practice speaking according to } \\
\text { the choices preferred by students }\end{array}$ & $\begin{array}{l}\text { The type of } \\
\text { speaking practice } \\
\text { is determined by } \\
\text { students }\end{array}$ & \\
\hline 13 & Yanto & $\begin{array}{l}\text { Given freedom in the practice of } \\
\text { speaking with material that is free } \\
\text { and in ways that are creative and } \\
\text { unique so that the impression is } \\
\text { not rigid }\end{array}$ & $\begin{array}{l}\text { Student get a } \\
\text { freedom to be } \\
\text { creative } \\
\text { speaking activities. }\end{array}$ & \\
\hline 14 & Lisa & \begin{tabular}{|lrrr} 
Preparation & \multicolumn{2}{r}{ before } & \multicolumn{2}{r}{ speaking } \\
practice so that I am & more \\
confident because I & have \\
mastered the topic & of \\
conversation & &
\end{tabular} & $\begin{array}{l}\text { Students can make } \\
\text { good preparation } \\
\text { materially and } \\
\text { mentally }\end{array}$ & \multirow{3}{*}{$\begin{array}{l}\text { The stages of } \\
\text { the speaking } \\
\text { production } \\
\text { through vlogs } \\
\text { can increase a } \\
\text { high level of } \\
\text { confidence. }\end{array}$} \\
\hline 15 & Nona & $\begin{array}{l}\text { The practice of speaking through } \\
\text { vlogs uses indirect methods so } \\
\text { we can prepare ourselves to } \\
\text { speak well so that it is not } \\
\text { embarrassing later when watched }\end{array}$ & $\begin{array}{l}\text { There is a good } \\
\text { self-preparation in } \\
\text { speaking activities }\end{array}$ & \\
\hline 16 & Patris & $\begin{array}{l}\text { I can know and assess their own } \\
\text { speaking style before being } \\
\text { displayed in front of the class. }\end{array}$ & $\begin{array}{l}\text { Students conduct } \\
\text { an independent } \\
\text { assessment of } \\
\text { speaking activities }\end{array}$ & \\
\hline 17 & Yoga & $\begin{array}{l}\text { The practice of speaking using } \\
\text { vlogs can reduce speech errors } \\
\text { such as pronunciation, intonation, } \\
\text { gestures. Because before it was } \\
\text { displayed I revised and repeated } \\
\text { the conversation until it was } \\
\text { really good. }\end{array}$ & $\begin{array}{l}\text { Students do } \\
\text { independent } \\
\text { revisions } \\
\text { repeatedly }\end{array}$ & \multirow{4}{*}{$\begin{array}{l}\text { The stages of } \\
\text { the speaking } \\
\text { production } \\
\text { activities } \\
\text { through vlogs } \\
\text { such as a } \\
\text { material } \\
\text { preparation, } \\
\text { speaking } \\
\text { activities and } \\
\text { self- } \\
\text { assessment } \\
\text { can increase a } \\
\text { high level of } \\
\text { confidence }\end{array}$} \\
\hline 18 & Andini & $\begin{array}{l}\text { I can know and assess their own } \\
\text { speaking style before being } \\
\text { displayed in front of the class. }\end{array}$ & $\begin{array}{l}\text { Students conduct } \\
\text { an independent } \\
\text { assessment of } \\
\text { speaking activities }\end{array}$ & \\
\hline 19 & Norma & $\begin{array}{l}\text { The practice of speaking using } \\
\text { vlogs can reduce speech errors } \\
\text { such as pronunciation, intonation, } \\
\text { gestures. Because before it was } \\
\text { displayed I revised and repeated } \\
\text { the conversation until it was } \\
\text { really good. }\end{array}$ & $\begin{array}{l}\text { Students do } \\
\text { independent } \\
\text { revisions }\end{array}$ & \\
\hline 20 & Fian & Preparation before speaking up & Student & \\
\hline
\end{tabular}




\begin{tabular}{|c|c|c|c|c|}
\hline & & $\begin{array}{l}\text { so that you are more confident } \\
\text { because you have mastered the } \\
\text { topic of conversation }\end{array}$ & $\begin{array}{l}\text { good topic and } \\
\text { discussion } \\
\text { material }\end{array}$ & \\
\hline 21 & Yosep & $\begin{array}{l}\text { The practice of speaking through } \\
\text { vlogs uses indirect methods so } \\
\text { we can prepare ourselves to } \\
\text { speak well so that it is not } \\
\text { embarrassing later when watched }\end{array}$ & $\begin{array}{l}\text { Students do self- } \\
\text { preparation for the } \\
\text { mental and aspects } \\
\text { of good speech }\end{array}$ & \\
\hline 22 & Oris & $\begin{array}{l}\text { There is a stage of evaluation and } \\
\text { revision of itself so that it knows } \\
\text { and corrects errors of speech } \\
\text { before being watched and } \\
\text { published }\end{array}$ & $\begin{array}{ll}\text { Students do the } \\
\text { assessment and } \\
\text { revision }\end{array}$ & \\
\hline 23 & Ito & $\begin{array}{l}\text { In our speaking course we watch } \\
\text { each other's vlogs and give } \\
\text { comments so that each one } \\
\text { knows the deficiencies in } \\
\text { speaking. }\end{array}$ & $\begin{array}{l}\text { Students watch } \\
\text { and give an } \\
\text { assessment in the } \\
\text { form of comments } \\
\text { on the vlog of } \\
\text { talking to each } \\
\text { other }\end{array}$ & \multirow[t]{2}{*}{$\begin{array}{l}\text { Vlog results } \\
\text { are displayed } \\
\text { and evaluated } \\
\text { by classmates } \\
\text { on the practice } \\
\text { of speaking in } \\
\text { class }\end{array}$} \\
\hline 24 & Luis & $\begin{array}{l}\text { The results of vlogs that we made } \\
\text { are watched together in class so } \\
\text { that I always display the best } \\
\text { speaking activities and it will not } \\
\text { look embarrassing. }\end{array}$ & $\begin{array}{l}\text { Students supposed } \\
\text { to look } \\
\text { embarrassing } \\
\text { when the vlog is } \\
\text { watched by } \\
\text { lecturers and } \\
\text { classmates }\end{array}$ & \\
\hline 25 & Ria & $\begin{array}{l}\text { In speaking course, we were } \\
\text { assigned to share videos on } \\
\text { YouTube to be watched by many } \\
\text { people, after receiving input and } \\
\text { direction from friends and } \\
\text { lecturers. We could have the best } \\
\text { vlog show, so others can } \\
\text { understand the conversation and } \\
\text { enjoy watching it. }\end{array}$ & $\begin{array}{l}\text { Students could } \\
\text { show their } \\
\text { activities of } \\
\text { talking through the } \\
\text { vlog optimally } \\
\text { because it will be } \\
\text { published and } \\
\text { watched by many } \\
\text { people through } \\
\text { social media. }\end{array}$ & \multirow[t]{2}{*}{$\begin{array}{l}\text { There is a duty } \\
\text { to publish } \\
\text { vlogs made to } \\
\text { social media }\end{array}$} \\
\hline 26 & Alex & $\begin{array}{l}\text { Speaking activities will be } \\
\text { published on YouTube, making } \\
\text { me the maximum in correcting } \\
\text { aspects of speaking errors that } \\
\text { have been assessed by lecturers } \\
\text { and friends so they don't look } \\
\text { embarrassing when watched by } \\
\text { many people. }\end{array}$ & $\begin{array}{l}\text { Students could } \\
\text { revise the speaking } \\
\text { errors according to } \\
\text { the assessment of } \\
\text { lecturers and other } \\
\text { students optimally } \\
\text { before they are } \\
\text { published on } \\
\text { social media }\end{array}$ & \\
\hline 27 & Ridho & $\begin{array}{l}\text { Learning to use vlogs is very } \\
\text { interesting because it is in great }\end{array}$ & $\begin{array}{l}\text { Vlog is very } \\
\text { popular with many }\end{array}$ & $\begin{array}{l}\text { Vlogs are the } \\
\text { trend in the }\end{array}$ \\
\hline
\end{tabular}




\begin{tabular}{|c|c|c|c|c|}
\hline & & $\begin{array}{l}\text { demand by many people and is a } \\
\text { trend on social media. }\end{array}$ & people & \multirow{2}{*}{\begin{tabular}{ll}
\multicolumn{2}{|l}{ development } \\
of $\quad$ social \\
media in \\
current era
\end{tabular}} \\
\hline 28 & Paula & $\begin{array}{l}\text { The learning uses a growing } \\
\text { digital social trend that makes us } \\
\text { happy to follow the learning } \\
\text { process }\end{array}$ & $\begin{array}{lr}\text { Students } & \text { are } \\
\text { interested } & \text { in } \\
\text { learning } & \text { using } \\
\text { digital } & \text { media } \\
\text { which is popular } \\
\text { in the current era }\end{array}$ & \\
\hline 29 & Hans & $\begin{array}{l}\text { I am very interested in learning } \\
\text { Indonesian speaking skills using } \\
\text { vlogs because I am very } \\
\text { interested in the field of } \\
\text { videography }\end{array}$ & $\begin{array}{l}\text { Students expected } \\
\text { will interest in } \\
\text { learning related to } \\
\text { videography } \\
\text { (multimedia) }\end{array}$ & $\begin{array}{l}\text { Vlogs that } \\
\text { Interest in } \\
\text { multimedia } \\
\text { (videography) }\end{array}$ \\
\hline
\end{tabular}

Based on the table of student perspective related to learning motivation in learning project based learning based on using vlogs, the "cause" motive is explained in two context categories, namely in terms of the learning process of speaking Indonesian language skills and in terms of vlog phenomena.

\section{1) Student Learning Motivation Judging from the Project Based Learning Process Using Vlog}

Based on the data analysis result, some informants have a "cause" motive in terms of the learning process using vlogs, including:

\section{a) Students feel unsaturated in explaining the material that is associated with speaking activities through watching vlogs.}

This study shows that lecturers use learning strategies using vlogs as a learning medium in delivering and explaining material proven to reduce the saturation of students in the learning process. The material discussed is sourced from the results of vlogs that are presented in class. Vlogs watched consist of two types, between types of vlogs with good speaking techniques and types of vlogs with poorly speaking techniques. Every discussion related to the aspect of speaking is always given an example through watching a vlog that lasts between 1-5 minutes, for example the components of language related to pronunciation, clarity, expression, expression, sentence structure, body movements, eye sight, and so on. Through giving examples of speaking using vlog media, students are indirectly invited to see other contexts so that they get a variety of variants in receiving material. This makes students become excited and do not feel bored in the learning process.

Based on data analysis in this study, it shows that the material discussion strategy using vlogs as an example of the main source of speaking skills is considered to be able to attract students' learning interest because students feel not saturated with the discussion of the material which is always interspersed with vlog examples in each sub-section. Coupled with material about videography that makes students' curiosity increasingly evidenced by the active question and answer to lecturers.

b) The clarity of the material given by the lecturer which is associated with the viewing of speaking activities on the vlog presented in class.

Explanation of material on speaking skills associated with examples of speaking through vlogs stimulates the cognitive aspects of students to make it easier to understand and 
comprehend the material being taught. Such as the pronunciation aspect, the lecturer gives an explanation and gives an example of speaking with good pronunciation through watching vlogs. Students feel that the delivery strategy of the material linked in the vlog viewing makes them more quickly understand. So that when they can understand a material it will increase motivation to learn and if they do not understand a material it will decrease motivation to learn.

Besides that, the lecturer gives a little material related to techniques of making vlogs or material about videography and matters relating to speaking skills in front of the camera. It is useful related to the practice of speaking using vlogs so that students can create vlogs with good results related to speaking techniques framed in audio-visual form.

\section{c) Tasks and discussions based on cases of speaking on vlogs}

After getting the delivery of material from the lecturer, students are invited to discuss to provide an assessment in the form of responses, comments and suggestions on the vlogs they watch. The lecturer sends the vlog through the whatsapp group in the form of a vlog URL then asks each student to watch through their respective devices and record and comment on the speaking errors found in the vlog. After that, each student is given the opportunity to present his findings and provide comments and suggestions on the speaking activities that are watched in the vlog. This learning strategies are called inquiry strategies and problem solving. Students are invited to think critically with expressing their opinions related to improvements in speaking errors and the material presented. Then the responses from students are completed and discussed together with lecturers in class.

This strategy is considered quite good, because it can increase the active attitude and responsibility of students in expressing opinions, correcting and providing input related to the material and speaking activities through vlogs presented by each student. So that it can be said that the assessment in the form of comments and suggestions from colleagues is a high motivation to learn speaking skills using vlogs. This is in line with that suggested by Mulyasa (2003: 186) through nine ways, including understanding and mastering the material and its relationship with other materials well and connecting past experiences with the material taught. Sardiman (2006: 147-150) also proposed suggestions related to creating good conditions between teachers and students, namely by making contact-hours.

\section{d) The type of speaking practice and the topic of conversation are determined based on students' interests}

After understanding the material of speaking skills, students are asked to make vlog products related to speaking activities. Students are given the freedom to choose the type of speaking activities such as matters relating to monologues, among others, the host, reporters, speeches, sermons, pulpit motivators, the practice of dialogue including conversation, debate, and resource persons. In addition, topics that become material in the practice of talks are chosen based on students' interests, such as sports, music, fashion, education, and etc. This is useful to encourage enthusiasm and ability to practice speaking. Based on the perspective of students in table 1 above, it can be said that the topic of conversation based on interest in speaking activities is liked by students so that it has an influence on increasing student learning motivation in learning speaking skills.

\section{e) The stages of production are carried out regularly and the practice of speaking is indirect}

Project Based Learning is a learning that produces products. The products that will be produced by students are vlog products. The design of speaking practice using vlogs in learning 
does not use the direct method, but it uses the indirect method. That is, the practice of speaking using vlogs is done outside the classroom. Students are divided into study groups, then produce a speaking activity through vlogs. The vlog product results will be presented in front of the class in groups. The practice of speaking using vlogs includes the preparation stage, activities of speaking through vlogs, independent assessment, independent revision, assessment of students and lecturers. (1) the preparation phase begins with the preparation of topics and materials independently according to the interests and fondness of students. Students seek information and design the process of conversation creatively. Then the next preparation is the preparation of tools such as cameras, microphones related to videography. (2) Speaking activities, students conduct speaking activities in front of the camera in accordance with the topic of conversation. (3) Self-assessment, students in each group reflect independently and periodically related to speaking activities that have been carried out by paying attention to linguistic components such as pronunciation, intonation, sound pressure, clarity, sentence structure, expressions, gestures, eye sight, clarity, and fluency in talking. (4) After reflecting, students repeat speaking activities according to the results of the reflections. The process of reflection and revision can be done repeatedly until getting maximum results in producing a product of speaking activities through vlogs.

Based on the data analysis result, the practice of using video blogs can reduce fear and embarrassment when speaking because it is indirect in public. Students are able to mobilize all their speaking abilities freely without any intervention from other parties. This is in line with what was said by Sucipto (2012) that speaking freely can train mentally well in order to improve one's speaking skills. In addition, students can indirectly master the learning material in conversations made in the video blogging. So, when a student is asked to take responsibility for speaking related to the assignment given in front of the class, he no longer has difficulties when speaking in front of the class because he has mastered the material and has trained mental processes so that it affects the students' speaking competence. Therefore, the stages in making vlogs are very popular for students because they can practice aspects of speaking skills and mental aspects systematically and periodically. So it can be said that the stages of vlog production on a regular basis which are done outside the classroom (indirectly) can affect the increase in students' motivation in learning PBL-based speaking skills using vlogs.

\section{f) Vlog Results of speaking activities that have been made by each group are shown in class and get an assessment from each student.}

Each group is required to present their vlog results using the LCD projector and watch together in class, and then will be assessed by classmates in the form of responses, comments and suggestions related to aspects of speaking and other aspects related to vlogs. The results of these responses will be complemented by lecturers related to improvements in aspects of speaking and creativity in making vlogs to be better in the next process. It is intended that each student can show maximum results in speaking activities through vlogs.

Beside this is can make students able to make maximum vlog results, joint assessment can also encourage students to actively participate in learning activities. All the phenomenon that are seen in this teaching and learning speaking skills in the classroom that are students tend to actively listen seriously to each learning process, actively participate in expressing opinions, revise classmates' speaking errors, and make conclusions in multiconcepts. In line with the perspectives of students presented in the table above, that they do not want to look embarrassing when the vlog is watched and assessed together and through a joint assessment can influence the high motivation of student learning. It proves that the dominance of student activity in learning speaking skills has implications for the role of instructors as teacher, as a mentor, as a counselor, 
as a scientist, as person which is well realized in the classroom.

\section{g) The task of publishing vlogs created through the YouTube platform}

After making revisions related to aspects of speaking and aspects of videography, vlogs that have been made are then distributed via the YouTube platform and shared on various digital platforms such as Instagram, Facebook, Twitter and so on. From this, many people can watch it. The vlog with the most and the best viewers will be given a reward from the lecturer. The purpose of publishing and giving rewards is to encourage students to be able to produce vlogs by speaking in accordance with good and correct aspects of language. Based on the perspective of students, the task is to publish vlogs via YouTube, some respondents stated that they felt compelled to improve their speaking skills properly and correctly and were creative in their presentation so that they did not look embarrassing and could be liked by many people who watching through social media.

\section{2) Students' motivation in terms of Vlog Media Phenomenon}

From the results of the study, several informants had a "cause" motive reviewed by vlog media, including:

\section{a) Vlogs are a trend in the development of social media in the current era}

The existence of vlogs now shows a very significant thing. The rapid development of vlogs does not require a long time. Since its inception in 2000 until now, vlogs have become the production and consumption of many people in various countries. The development of vlogs is inseparable from the rapid development of YouTube as a digital platform. "We are social" is one of the social media statistics sites released that since January 2016, the total calculation of internet users in Indonesia is 88.1 million from a total Indonesian population of 259.1 million. Experienced a growth of around 15\% from the previous year. Then, YouTube claims that almost one third of all internet users in the world visit YouTube and the growth of watch time on YouTube is accelerating and it is at least increasing by $50 \%$ continuously in this three years. According to Green (Eka Dian Susanti, 2019: 88) revealed that vlogging is one form of content that is very dominant on the Youtube platform. So it is clear that Vlog is a media that cannot be underestimated with its influence in Indonesia. The phenomenon of vlogs as a means of entertainment and information currently greatly affects the world community especially the people of Indonesia as a pro-gadget society. This thing is proven by some words or vlog jargon in our memories such as "guys", "don't forget to like, to comment, to subscribe and press the bell". It proves that vlogs are currently becoming a world trend and it can be said that every vlog user hits or slang person.

Utilizing the popularity of vlogs into learning is a multimedia-based strategy that encourages students' interest in the teaching and learning process especially speaking skills. So the learning of speaking skills can go hand in hand with an interest in the phenomenon of social media using vlogs as a forum for channeling opinions, suggestions, stories of experience, criticism, tutorials and so on.

\section{b) Interest in the field of multimedia (videography)}

The main attraction regarding vlog learning media is the addition of multimedia knowledge for students such as videography techniques, and YouTube taught by lecturers. Students tend to actively listen well to the material on the vlog procedural making. their attractiveness towards the multimedia field made them enthusiastic in participating in the multimedia-based learning. In addition, they are very active asking to the lecture about the 
technical matters related to making vlogs in the production process. The link between learning and multimedia (videography and YouTube social media) is the main attraction in increasing students' interest in learning Indonesian language speaking skills.

\section{In Order to Motives}

In order to motives is the motive of an action oriented to the future as the reason for the action, this is done in order to achieve certain goals to be achieved in the future (Campbell, 1994: 271). From the results of the questionnaire and interviews with the informants, there are several informants who have motivation to learn based on the motive of "goals", this is because there are certain goals that the informants want to obtain in the future in learning speaking skills using vlogs. We can see matters in this study relating to the meaning and theme as the motive of "goals" in the following table:

Table 2. "In Order to Motives" Student Learning Motivation in Learning Speaking Skills Using Vlogs

\begin{tabular}{|c|c|c|c|c|}
\hline No & Respondents & Social Context & Meaning & Theme \\
\hline 1 & All Students & $\begin{array}{l}\text { All students gave the same } \\
\text { response that they wanted to learn, } \\
\text { to train their mental abilities and } \\
\text { improve their speaking skills } \\
\text { properly and correctly }\end{array}$ & $\begin{array}{l}\text { Students want } \\
\text { to practice the } \\
\text { ability to speak } \\
\text { properly and } \\
\text { correctly }\end{array}$ & $\begin{array}{l}\text { The desire to } \\
\text { develop } \\
\text { Indonesian } \\
\text { speaking skills } \\
\text { properly and } \\
\text { correctly } \\
\text { without feeling } \\
\text { nervous. }\end{array}$ \\
\hline 2 & Rendi & I want to train mentally in speaking & $\begin{array}{l}\text { Students } \\
\text { mentally train } \\
\text { when talking }\end{array}$ & \multirow{4}{*}{$\begin{array}{l}\text { The desire to } \\
\text { improve mental } \\
\text { aspects of } \\
\text { speaking } \\
\text { activities }\end{array}$} \\
\hline 3 & Okta & $\begin{array}{l}\text { I want to be more confident when } \\
\text { talking }\end{array}$ & $\begin{array}{l}\text { Students want } \\
\text { to practice } \\
\text { speaking skills }\end{array}$ & \\
\hline 4 & Rio & $\begin{array}{l}\text { I want to be able to speak properly } \\
\text { and correctly }\end{array}$ & $\begin{array}{l}\text { Students' } \\
\text { desire is to } \\
\text { have } \\
\text { confidence } \\
\text { when speaking }\end{array}$ & \\
\hline 5 & Bram & $\begin{array}{l}\text { I want to be able to speak without } \\
\text { feeling nervous and afraid }\end{array}$ & $\begin{array}{l}\text { Students do not } \\
\text { want talk } \\
\text { fearlessly and } \\
\text { nervously }\end{array}$ & \\
\hline 6 & Aris & $\begin{array}{l}\text { I want to practice speaking skills so } \\
\text { that later I will get good grades in } \\
\text { this course }\end{array}$ & $\begin{array}{l}\text { Students want } \\
\text { to get satisfying } \\
\text { value }\end{array}$ & \multirow[t]{2}{*}{$\begin{array}{l}\text { The desire to } \\
\text { get results and } \\
\text { good grades }\end{array}$} \\
\hline 7 & Erni & $\begin{array}{l}\text { I want to improve my academic } \\
\text { grades this semester }\end{array}$ & $\begin{array}{l}\text { Students could } \\
\text { increase their } \\
\text { academic value }\end{array}$ & \\
\hline 8 & Ardi & $\begin{array}{l}\text { At the moment I am working in a } \\
\text { vlogger job, so the subject of } \\
\text { speaking skills using vlog is very }\end{array}$ & $\begin{array}{l}\text { Students want } \\
\text { to make a lot of } \\
\text { speaking }\end{array}$ & $\begin{array}{l}\text { Students' desire } \\
\text { to be a Vlogger }\end{array}$ \\
\hline
\end{tabular}




\begin{tabular}{|l|l|l|l|l|}
\hline & & $\begin{array}{l}\text { suitable for me to be able to } \\
\text { produce a lot of vlogs with various } \\
\text { contents. }\end{array}$ & $\begin{array}{l}\text { activities in the } \\
\text { form of vlogs }\end{array}$ & \\
\hline 9 & Ano & $\begin{array}{l}\text { This learning made me more } \\
\text { interested in the world of vlogs and } \\
\text { wanted to become a vlogger }\end{array}$ & $\begin{array}{l}\text { Students are } \\
\text { Interested in } \\
\text { becoming a } \\
\text { vloger }\end{array}$ & \\
\hline 10 & Ira & $\begin{array}{l}\text { Through this learning, I came to } \\
\text { know ways to make good vlogs } \\
\text { with interesting stories and earn } \\
\text { extra income }\end{array}$ & $\begin{array}{l}\text { Students want } \\
\text { to earn income } \\
\text { through vlogs }\end{array}$ & $\begin{array}{l}\text { The students' } \\
\text { desire to earn } \\
\text { income through } \\
\text { the generated } \\
\text { Vlog }\end{array}$ \\
\hline
\end{tabular}

Based on table of the student perspective related to the learning motivation in project using vlogs, the "goal" motive is explained in two context categories, namely in terms of the learning process of speaking Indonesian language skills and in terms of vlog phenomena.

1) "In Order to Motives" Viewed from the Learning Process

Based on the meaning of the perspective of students in the table above, classified the motive "goals" in terms of the learning process, including:

\section{a) The desire to develop Indonesian speaking skills properly and correctly}

Referring to learning achievements (CP), the learning objectives of speaking skills at PBSI Nusa Cendana University are students capable of (a) mastering the basic concepts of speaking skills (speaking as language skills, level of speaking skills, speaking goals, types of speaking activities, determinants of communication speaking, (b) conveying the contents of messages, information, desires, feelings, and knowledge for various purposes of verbal communication using Indonesian language properly and correctly. This learning achievement is in line with the goals of all students to develop their respective speaking competencies. The mastery of Indonesian language speaking skills becomes the basic capital for learning motivation. To achieve the learning objectives the role and cooperation of all parties involved in learning are needed. According to Uno (2011), Students' goals that they want to achieve are the factors that influence the high motivation of learning. The indicators that influence learning motivation are (1) the existence of desires and desires to succeed (2) there are encouragement and needs in learning, (3) there are hopes and ideals of the future, (4) there is an appreciation in learning, (5) the existence of interesting activities in learning, (6) the existence of a conducive learning environment.

\section{b) Desire to improve mental aspects of speaking activities}

Basically, speaking activities related to linguistic factors and mental factors of a person. Continuous training is needed to be able to speak and communicate skilfully. Mental factors cannot be separated from one's ability to speak. Mental factors cannot form properly in a short time, but are formed from the habits of speaking and the experience of speaking in public spaces. The activity of speaking through vlogs is an approach to speaking skills that can stimulate students' mental processes on a regular basis through stages such as the development of insights, speaking exercises according to aspects of speaking skills, evaluation of speaking independently, and publication.

\section{c) The desire to get the best value}


One of the goals of student respondents is to get satisfactory academic achievement. This is an achievement in learning in the form of values as a measurement of learning outcomes. The purpose of getting a good academic achievement will use the ability to understand the material and do the tasks well so that it will have implications for good academic achievement according to the learning objectives. This is consistent with what is said by Saiful (2015: 253) that students with high academic self-concepts will show high academic achievement, whereas students with low academic self-concepts tend to show low academic achievement. Based on this opinion it can be said that the goal of "wanting to get good academic achievement" is a self-concept towards high academic goals so that the self-concept increases student motivation to obtain maximum results.

2) "In Order to Motives" Viewed from the Learning Process

Based on the meaning of the perspective of students in the table above, classified a number of in order to motives in terms of vlog phenomena, including:

\section{a) Desire to become a Vlogger}

Currently, the popularity of vlogs in the digital era is very influential in Indonesian society especially young people. As a pro gadget community, you will always meet vlog content when you are active in cyberspace or social media. The rise of watching vlogs on social media makes some people participate in creating vlogs that can be shared with many people as a form of self-actualization. It also happened to several student informants in this study. The aim of becoming a vlogger is to make them interested in developing speaking competence and mental training through learning speaking skills that use vlogs as learning media.

\section{b) The desire to earn income through vlog works}

Today, the development of digital media not only as a forum to publish various things in life but also can bring benefits to its users. One of the digital platforms that is widely used and can provide financial benefits is YouTube. YouTube is a digital platform that functions to publish videos in a long duration. This digital platform provides various awards in the form of money and souvenirs to its users with certain conditions such as the large number of viewers, many followers of the account owner, and so on. Many Vloggers today use YouTube as a job because it can bring in considerable income.

This phenomenon encourages students' interest so that they compete to practice their speaking skills to produce various vlogs that are published through the digital youtube platform. This interest makes them become more active in participating in speaking skills to produce various vlogs. Not only videos that are suitable with the subject of speaking skills, but they produce videos with various genres such as culinary, fashion, make-up, culture, tourism and etc.

\section{CONCLUSION}

Motivation is very important in learning. This research proves that there is the motivation of speaking skills of Indonesian Language and Literature Education Department students uses high vlogging media. This can be seen from the variety of students' interest in participating in learning based on because of motives and in order to motives which are classified in two contexts namely the context of the application of learning and the vlog phenomena. In general, learning speaking skills associated with vlogs can attract students 'learning interest. This is because it is related their interest in learning strategies, students' interest in multimedia technology and internet social media. This interest has implications for increasing student learning motivation so that learning objectives can be achieved properly. 
Bisides to improving aspects of Indonesian speaking skills, the application of learning PBLbased speaking skills through vlog media can gradually improve the mental aspects of students to become more confident to speak and communicate in public through various stages. So it can be said that learning PBL-based speaking skills using vlogs is a good and innovative learning strategy in an effort to improve students' speaking skills to be more critical and creative and have good mental abilities. It proves that the dominance of student activity in learning speaking skills has implications for the role of instructors as teacher, as a mentor, as a counselor, as a scientist, as person which is well realized in the classroom.

The character of $21 \mathrm{st}$ century learning that is often referred to as $4 \mathrm{C}$ Communication (Communication), Collaboration (Collaboration), Critical Thinking and Problem Solving (Critical Thinking and Problem Solving), and Creativity and Innovation (Creativity and Innovation) can also be found in this learning strategy. And in the end it able to provide competitive advantage (competitive adventage) to a nation in the Industrial Revolution 4.0 era that actually manifests the ability to integrate a variety of resources in order to have connectivity in the mastery of technology, communication, and big data to produce 'smart products' and' smart services'.

\section{REFERENCES}

Bungin, Burhan (Ed.). (2006). Metodelogi Penelitian Kualitatif. Jakarta: PT Raja Grafindo Persada. Campbell, Tom. (1994). Tujuh Teori Sosial. Yogjakarta: Kanisius.

Creswell, John W. (2017). Penelitian Kualitatif \& Desain Riset. Yogyakarta : Pustaka Pelajar.

David, Eribka Ruthellia, Mariam Sondakh Stefi Harilama. (2017). Pengaruh Konten Vlog dalam Youtube terhadap Pembentukan Sikap Mahasiswa Ilmu Komunikasi Fakultas Ilmu Sosial dan Politik Universitas Sam Ratulangi. Acta Diurna. Vol 6(1) Hal 143-157.

Djamarah, Syaiful Bahri dan Aswan Zain. (2002). Strategi Belajar Mengajar. Jakarta: Rineka Cipta. Djamarah, Syaiful Bahri. (2002a). Psikologi Belajar. Jakarta: Rineka Cipta.

Djiwandono, Sri Esti Wuryani. (2004). Psikologi Pendidikan. Jakarta: Grasindo.

Faizah, Mohammad Fakhrudin, Bagiya. (2017). "Implementasi Media Pembelajaran Youtube Retorika Dakwah Pendidikan Berbasis Pendekatan Ilmiah di Universitas Muhamadiyah Purworejo". Prosiding SAGA. Universitas Muhamadiyah Purworejo.

Fatmawati, Putri Yuniar. (2017). Pengaruh Metode Bermain Peran dengan Video dan Motivasi Belajar terhadap Keterampilan Berbicara Bahasa Inggris Kelas VI SDN 1 Rangkas Bitung Timur. Jurnal Pendidikan. STKIP Setia Budi Rangkasbitung. Vol 1 (1) Hal. 9-17

Febriana, Meike Bela , Fahmi Wayuningsi. (2019). "Learning Results of German Language Skills Speaking using Video Learning Media Based on Powtoon Applications". Internasional Journal of Unesa. Universitas Negeri Surabaya. Vol 15(2) Hal 334-347.

Mahanal, S. \& Wibowo, A.L.( 2009). Penerapan Pembelajaran Lingkungan Hidup Berbasis Proyek untuk Memberdayakan Kemampuan Berpikir Kritis, Penguasaan Konsep, dan Sikap Siswa (Studi di SMAN 9 Malang). Makalah Disajikan dalam Seminar Nasional Pendidikan Lingkungan Hidup dan Interkonferensi BKPSL. Universitas Negeri Malang. 20- 21 Juni 2009-07-15.

Mulyasa, E. (2003). Kurikulum Berbasis Kompetensi: Konsep, Karakter, dan Implementasinya. Bandung: PT Remaja Rosdakarya.

Muhamad Sofian Hadi, Emzir. (2016). Improving English Speaking Ability Througth Mobile Assisted Language Learning (MALL) Learning Model. International Journal of Language Education and Culture Review (IJLECR), Vol.2 (2), 71-74.

Pribadi, Benny A.9. (2009). Model Desain Sistem Pembelajaran. Jakarta: PT Dian Rakyat. Saifullah. (2015). Hubungan Konsep Diri Akademik dengan Prestasi Akademik . Jurnal Lisan AlHal. Vol 9 (2). Hal 251-259 
Sanjaya, Wina. (2009b). Strategi Pembelajaran Berorientasi Standar Proses Pendidikan. Jakarta: Kencana.

Sardiman. (2006). Interaksi dan Motivasi Belajar Mengajar. PT RajaGrafindo Persada.

Setiawardani Wawan. (2016). "Penggunaan Media Audio Visual pada Pembelajaran Bahasa Indonesia untuk Meningkatkan Keterampilan Berbicara Siswa Kelas IV SDN Barunagri Lembang". UPI Press

Siti Yulidhar Harunasari, Aceng Rahmat. (2015).CALL-BASED INSTRUCTION MODEL OF SPEAKING ENGLISH (A Developmental Research at the English Language Education Study Program of STKIP Kusuma Negara, Jakarta). International Journal of Language Education and Culture Review (IJLECR).Vol.1(1), 65-78.

Sri Wahyu Indrawati, Emzir, dan Ninuk Lustyantie. (2017). The Effect of Learning Teachnique and self Confidence Toward to Students Speaking Skill In Indonesian Discussion (Experimental Study of the $17^{\text {th }}$ National Senior High School Palembang. International Journal of Language Education and Culture Review (IJLECR). Vol 3 No 2.

Sumiati dan Asra. (2007). Metode Pembelajaran. Bandung: CV Wacana Prima.

Suparman, Atwi. (1993). Desain Instruksional. Jakarta: Pusat Antar Universitas.

Supriyadi. (2005). Interaksi dan Motivasi Belajar Mengajar. PT RajaGrafindo Persada.

Tarigan, Djago.dkk. (1998). Pengembangan Keterampilan Berbicara. Jakarta: Depdikbud Bagian Proyek Penataran Guru SLTP setara D III.

Willis, J. (2010). A Framework for Task-Based Learning. Edinburgh: Longman. 